\title{
A ESCRITA COMO RESISTÊNCIA EM ANTÓNIO LOBO ANTUNES
}

Glaura Siqueira Cardoso

Vale*

RESUMO: A Guerra Colonial como cenário e contexto de produção está implicada nos romances iniciais de António Lobo Antunes, que, conjugados com as cartas que marcam esse período, são um importante materia de pesquisa para verificar a escrita e a leitura como resistência. Este artigo procura mostrar como a urgência de um projeto (os livros por vir) é também uma forma de sobrevivência à traumática experiência da guerra bem como o despertar de um trabalho contínuo de observação e filtragem da memória do autor a corroborar a composição de sua escrita.

PALAVRAS-CHAVE: António Lobo Antunes, Guerra colonial, Literatura portuguesa, Cartas

\begin{abstract}
* glaura.cardoso@gmail.com
Doutora em Literaturas Modernas e Contemporâneas pela FALE/UFMG. Bolsista do PNPD/Capes junto ao PPGCOM/UFMG.
\end{abstract}

ABSTRACT: Colonial War is present as the scene and production context of António Lobo Antunes' early novels, which combined with the letters of that period constitute an important research material for understanding the acts of writing and reading as forms of resistance. This article aims to show how the urgency of a project (the books to come) is a way of surviving to the traumatic experience of war, and also is the awakening of an uninterrupted work of observation and selection of the author's memory, reinforcing the composition of his writing.

KEYWORDS: António Lobo Antunes, Colonial War, Portuguese Literature, Letters 
1. ANTUNES. Os cus de Judas, p. 15.

2. ANTUNES. Os cus de Judas, p. 15.

3. RIBEIRO, Uma história de regressos, p. 265.

4. Memória de Elefante fala desse laço desfeito e de um certo deslocamento provocado pela não adaptação do médico no retorno da guerra. O personagem do romance está apartado de si mesmo restando a ele vagar pela cidade e espreitar (a poucos metros) as filhas que saem do colégio.

\section{É POSSÍVEL ESCREVER?}

Tinha força: tinha mulher, tinha filhas, o projecto de escrever, coisas concretas, boias de me aguentar à superfície.

António Lobo Antunes

Na altura em que publica seus primeiros romances, Memória de elefante (1979), Os cus de Judas (1979) e Conhecimento do inferno (1980), aproximadamente seis anos após o seu retorno da Guerra Colonial em Angola, António Lobo Antunes irá descrever o mundo interior da "casa portuguesa", mundo este em ruínas, uma vez que toma consciência das práticas de controle do regime sobre os sujeitos, em parte referendadas pela "casa" da qual é herdeiro: “- Felizmente que a tropa há-de torná-lo um homem". ${ }^{1}$ Em Os cus de Judas, seu segundo livro, a "casa portuguesa" é representada pela "casa das tias", cujo espectro de Salazar pairava e a PIDE "prosseguia corajosamente a sua valorosa cruzada contra a noção sinistra de democracia", 2 numa escrita marcada por um vocabulário "semanticamente unificado pela ideia de decadência e de fim". Nem mesmo o casamento, ${ }^{4}$ como instituição, sobreviverá a esse retorno. Tendo tudo isso em vista, não fica difícil constatar que seus romances iniciais contêm uma crítica feroz, uma espécie de grito, por assim dizer, contra a violência das instituições, Estado, Família e Hospital. O resultado da sua reflexão pode ser tomado como um "acerto" de contas, ou, ao menos, uma tentativa de elaboração do luto.
Em 2005, uma edição contendo as cartas de guerra de Lobo Antunes à sua primeira esposa, Maria José, intitulado D'este viver aqui neste papel descripto, traz, ao público leitor, um rico material em que essa violência expressa no texto já se encontra esboçada. Aqui, o leitor poderá verificar rastros da metodologia desenvolvida por Lobo Antunes na sua busca incansável pelos procedimentos de escrita, caminho que está ali registrado nos comentários das leituras empreendidas pelo autor em pleno campo de batalha. É possível perceber nas cartas que a guerra modificou o seu pensamento, a sua leitura em relação ao mundo; certo de que, em combate, não cabia a dúvida, era preciso estar ao lado dos seus camaradas para garantir a própria vida. Em sua análise sobre Os cus de Judas, Margarida Calafate Ribeiro reflete sobre essa questão que as cartas já anunciam:

Entre o medo e a solidariedade com os camaradas unidos pelo desejo de não morrer, a urgência de como médico salvar vidas e o desejo de "regressar inteiro", uma revolta surda contra a sua própria sociedade e estrutura militar e uma simpatia pela marginalidade e luta dos africanos e guerrilheiros, a quem atribui uma identidade própria e com quem começava a partilhar o estatuto de vítima de uma agressão, o narrador-personagem encontra-se sem espaço, num ambíguo compromisso entre o estar dentro sentindo-se de fora, revelando-se deste modo um outro sentido do título do romance, que claramente se destaca no episódio de Sofia. ${ }^{5}$
5. RIBEIRO. Uma história de regressos, p. 279. 
6. ANTUNES. Os cus de Judas, p. 28.

7. RIBEIRO. Uma história de regressos, p. 283.
Ao mesmo tempo em que denunciam o horror, num relato íntimo que expõe aquela experiência, as missivas apontam para a ternura infiltrando a guerra: a troca de amenidades com a esposa, bem como os retratos (em fac-símile) do progresso da gravidez de Maria José à imagem da filha que não viu nascer. Nesse jogo de sedução pela escrita, dado que a esposa é culta e politizada, transparece o leitor insone (de Céline a Tolstoi) e o escritor em formação. Se nas cartas a escrita da violência se dá com reservas, sobretudo em relação à tortura, pelo risco de serem abertas, em Os cus de Judas, a violência parece ser o próprio dispositivo da escrita. Logo no fim do primeiro capítulo desse romance, por exemplo, a descrição da cena do embarque dos soldados para Angola é ainda o momento e incerteza, embora já aponte para a certeza de que alguns não retornariam vivos, que a integridade dos corpos e espírito já se encontra em risco: "grandes caixões repletos de féretros ocupavam uma parte do porão, e o jogo, um pouco macabro, consistia em adivinhar, observando os rostos dos outros e o nosso próprio, os seus habitantes futuros. Aquele? Eu? Ambos?". ${ }^{6}$ Sem se ater muito a metáforas, o navio lembra a barca cujo único destino possível é a morte. Sobre isso Ribeiro diz que "o barco que levou a morte de Portugal para África traz [no regresso] a ruína da guerra, pedaços de homens destruídos nos cus de Judas, num universo circular e fechado de que parece não haver saída".
A descrição minuciosa da morte de combatentes, o que restou do espírito fraturado do jovem solado, até a impotência, sobretudo sexual, se dá numa narrativa estilhaçada, cujo tecido é perfurado por episódios indeléveis numa constante menção à violação do que seria o curso natural da vida de jovens caso pudessem optar pela não-experiência da guerra. Num efeito ritornelo, a guerra ora é tema, ora é refrão de outras experiências traumáticas, como a separação e o hospital psiquiátrico, pensando agora na trilogia, ambos os romances marcados pelo sentimento de impotência desse sujeito no mundo. Em relação a Os cus de Judas, para Ribeiro, há uma dimensão, através da impotência (sexual) transposta para o texto, de esterilidade da guerra e do colonialismo português, "esterilidade essa que desembarcou também em Portugal e se espalhou no país, manifesta na incapacidade de converter as ruínas em novas casas, encontros em relações de amor". ${ }^{8}$ A esse respeito, diz:

A excessiva e neurótica imagem de África, com os seus cheiros de morte e estropiamento, projecta-se em tudo, bloqueando o futuro. Está na casa, no amor, na cidade, em todo o mundo filtrado pelos olhos do narrador-persongem que se constitui o centro do seu mundo labiríntico e assumidamente marginal, construído "contra a corrente" (Antunes, 1991: 156) e do qual o mundo "normal" se afasta deixando a 'casa deserta' (...) Resta-lhe viver entre dois tempos (presente e passado) e dois
8. RIBEIRO. Uma história de regressos, p. 289-90.
EM TESE
BELO HORIZONTE
v. 20
N. 2
MAIO-AGO. 2014
VALE. A escrita como resistência em António Lobo Antunes
P. $150-170$ 
9. RIBEIRO. Uma história de regressos, p. 289. espaços (Portugal e África), cuja hibridez e permeabilidade denunciam uma encruzilhada dominada pela dor e pelo remorso de que resultam relações de amor-ódio, de dádiva-destruição, imagens extremas, pela combinação de opostos que oferecem, de impossibilidade, carência e solidão, sobre as quais nada de novo se pode construir. ${ }^{9}$

No caso das cartas, observa-se que o autor só pode se projetar para o futuro, sendo a escrita (que solicita a leitura) potência, vida. Já a transição da esfera do vivido para a ficção de suas memórias traz um sujeito (ou sujeitos) desenganado já maduro (ou amadurecido à força bruta) e amargurado Interessante perceber o percurso dessas duas vozes, o jovem apaixonado e o ex-combatente desenganado, sendo sua voz apenas um eco dessa experiência. Em D'este viver aqui neste papel descripto, constata-se a leitura e escrita como resistência. Resistência ao estado de guerra, resistência à solidão, à violação do corpo e da alma, resistência ao sentimento de impotência. Cartas que chegam também como documentos de um período violento da história de Portugal e de Angola, apontam, em âmbito privado, a implicação de um jovem aspirante a escritor numa guerra que culminou no fim do regime ditatorial que se mantinha desde 1926, tendo como data celebrativa do fim do regime salazarista a Revolução dos Cravos, em 25 de abril de 1974, a qual possibilitou a independência das colônias portuguesas em África, tardia em relação a outras ex-colônias europeias mediante o atraso no processo de democratização do país. Uma guerra intestina, conforme Roberto Vecchi observa, "uma guerra sem nome, uma história que resiste a encontrar seus nomes". ${ }^{10}$

Em Excepção atlântica, Vecchi indaga a respeito desse processo se questionando como seria possível pensar em fundar uma memória compartilhável quando "os despojos ainda não encontraram a sua sepultura. Sem luto haverá uma história possível?". ${ }^{11} \mathrm{O}$ crítico italiano se refere ao trabalho do luto como um "exercício de ontologizar restos e presentificá-los, transcrevê-los no presente". ${ }^{12}$ Em Os cus de Judas, por exemplo, observa-se, na voz do narrador, que os mortos formam também uma massa anônima, almas e corpos mutilados, como a própria narrativa. Corpos que passarão a pertencer a uma estatística, enquanto que para a família representam uma perda irreparável. A mutilação não é apenas física, os jovens soldados acabam condenados a conviver com a memória do horror. As cartas de guerra, quando chegam a público, confirmam aquilo que o romance trouxe à tona: a urgência do narrar, não para compensar essas perdas, mas para não esquecê-las. A escrita, no contexto da guerra, provoca uma fricção no real, ao passo que, nos livros por vir, será o real a perfurá-la. ${ }^{13}$

Sem pretender tomá-lo aqui como um testemunho, mesmo porque Lobo Antunes cria uma situação ficcional de

\begin{tabular}{|c|c|c|c|c|c|}
\hline EM TESE & BELO HORIZONTE & v. 20 & N. 2 & MAIO-AGO. 2014 & VALE. A escrita como resistência em António Lobo Antunes \\
\hline
\end{tabular}


encontro entre um personagem/narrador anônimo com uma mulher para narrar suas memórias, não assumindo diretamente o relato dessa experiência, Os cus de Judas talvez seja, dentre os três volumes da primeira fase, aquele que mais se aproxima do conteúdo de D'este viver aqui neste papel descripto. Talvez por se referir à mesma guerra, em que se percebe mais claramente um aproveitamento, por exemplo, de reflexões sobre o contexto, descrição e localização dos lugares por onde esteve (Gago Coutinho, Ninda, Chiúme, Marimba) e de imagens recorrentes "o céu de chumbo", " terra vermelha", "o calor a diluir os sentimentos mais fortes" "a ração de combate" partilhada com os outros, além de sentimentos como a "melancolia sem remédio", a saudade indescritível. Imagens descritas nas cartas e reaproveitadas pela filtragem da memória em Os cus de Judas. Nas cartas, o despertar para a escrita num contexto marcado pela iminência da morte; em Os cus de Judas, a escrita da violência.

Entende-se por testemunho as narrativas resultantes da experiência traumática, a exemplo, as dos regressos dos campos de concentração, como Primo Levi em É isto um homem? analisado por Giorgio Agamben em O que resta de Auschwitz. Grosso modo, seriam narrativas sobre a impossibilidade de testemunhar, uma vez que aqueles que não voltaram vivos seriam as verdadeiras testemunhas, os que têm muito a dizer (de dentro da própria morte), mas não podem dizer, e a experiência estaria para além da compreensão humana. No caso de Os cus de Judas, embora a Guerra Colonial possa ser uma experiência traumática, operando o autor no limite dessa impossibilidade de narrar a experiência, percebe-se que ao se apropriar de acontecimentos empíricos, sua preocupação primeira é a de renovar a arte do romance e sua busca incessante passa por essa tentativa, mesmo que para isso tenha que reinventar a própria experiência, narrando não necessariamente por aqueles que não podem mais dizer, mas pelos que voltaram vivos, como ele, obrigados a olhar para a própria ruína do império em decadência, constatando o quanto a guerra os tornara impotentes, e o quanto os soldados defuntos se tornaram fantasmas desse império. A esfera do vivido transformada, assim, em matéria de romance. Um livro intermediário. Entre a memória de elefante e o inferno.

Essa impossibilidade de construir sobre os "escombros imperiais" faz da casa, de andares desnudos, cujos canos murmuram um som defunto, "um lugar de morte, comparada a um jazigo vazio e hirto"14. Por outro lado, embora toda a impotência que a guerra possa ter deixado nos sujeitos, já regresso, ainda que não se possa "regressar" totalmente da guerra, ao escrever e publicar, o autor pôde, assim, por em prática o objetivo traçado em Angola. Lançando mão de uma espécie de acerto de contas com as instâncias de poder que oprimem, desqualificam e dilaceram os sujeitos, conforme
14. RIBEIRO. Uma história de regressos, p. 290. Conforme afirma: “Ficam ruínas de casas, de homens, de corpos, de impérios que só o texto fragmentário pode reerguer em preencham 0 gos de palavras que RIBEIRO Uma história de " 
15. ANTUNES. Os cus de Judas, p. 218.

16. RIBEIRO. Uma história de regressos, p. 278. dito anteriormente, como também fazer uma autorreflexão sobre a sua participação na guerra:

Mas não podíamos urinar sobre a guerra, sobre a vileza e corrupção da guerra: era a guerra que urinava sobre nós os seus estilhaços e os seus tiros, nos confinava à estreiteza da angústia e nos tornava em tristes bichos rancorosos, violando mulheres contra o frio branco e luzidio dos azulejos, ou nos fazia masturbar à noite, na cama, à espera do ataque, pesados de resignação e de uísque, encolhidos nos lençóis, à laia de fetos esbaforidos, a escutar os dedos gasosos do vento nos eucaliptos, idênticos a falanges muito leves roçando por um piano de folhas emudecidas. ${ }^{15}$

Relembrando a pergunta inicial lançada por Memória de elefante, "Onde é que eu me fodi?", convertida em Os cus de Judas por “Onde é que me foderam?”, Ribeiro salienta que:

nesta transferência do sujeito verbal - que implica uma transferência de responsabilidades - o narrador-personagem encontra a justificação, e alguma absolvição, para a violên cia e intransitividade dos actos de violação praticados pelos homens na guerra, lançando-se numa procura labiríntica simultaneamente autojustificativa (...) e acusatória dos culpados da sua situação. ${ }^{16}$
Para Lobo Antunes, conforme a estudiosa argumenta, "os culpados são aqueles que institucionalizaram a guerra, não ele". ${ }^{17}$ Uma pergunta que se pode fazer é o quanto a experiência da leitura diária nesse contexto, sobretudo de autores que refletem sobre a guerra, pôde modificar a sua escrita deixando vestígios nesse leitor/combatente e consequentemente em seu trabalho. $\mathrm{O}$ autor parece ter criado um método particular de sobrevivência, de resistência à pressão do mundo e aos discursos que o regem, no qual, em meio às obrigações militares, lia sistematicamente os livros enviados pela mulher, ao mesmo tempo em que iniciava seu projeto literário, a sua dolorosa aprendizagem da agonia, como Maria Alzira Seixo pontua.

\section{ESCREVER, RESISTIR}

Para pensar a complexidade do contexto de produção ao qual Lobo Antunes está implicado, e essa relação com a experiência traumática da violência, vale lembrar a análise de Boaventura de Sousa Santos sobre os três tempos simbólicos da relação das forças armadas e da sociedade portuguesa. O primeiro tempo, considerado o mais longo, que inclui o momento da guerra que Lobo Antunes participou, se refere ao “ir à tropa”. Sousa Santos apresenta a construção simbólica dos impactos da guerra na vida campesina, cuja obrigação do serviço militar tirava do convívio da família o ente querido e dois braços importantes da força de trabalho que mantinha a
17. RIBEIRO. Uma história de regressos, p. 278. 
18. Cena que remete ao silêncio dos soldados na chegada do primeiro companheiro morto vindo de uma missão no mar em They were expendable (1945), Homens para queimar, na tradução portuguesa, filme de guerra de John Ford.

19. SANTOS. Os três tempos simbólicos da relação entre as forças armadas e a sociedade portuguesa, p. 20.

20. ANTUNES. D'este viver aqui neste papel descripto, p. 48

21. ANTUNES. Os cus de Judas, p. 241. estrutura familiar e a economia, embora, para o jovem campesino, tivesse o atrativo do desconhecido, a promessa de descobrir um mudo maior, urbano, anônimo, a conquista de uma certa independência. Promessa de liberdade colocada à prova no capítulo "H", de Os cus de Judas, na longa descrição da chegada do primeiro morto ${ }^{18}$ ao acampamento. Também havia pais, segundo Sousa Santos, que abençoavam a dureza da vida militar "como meio de domar a rebeldia dos filhos", os quais "hão-de ir à tropa quebrar os narizes" o que continuou "a povoar e a assombrar o imaginário popular”. ${ }^{19}$ António Lobo Antunes apresenta isso de duas maneiras. Positivamente na carta de 10 de fevereiro de 1971, quando relaciona a tropa à experiência da escrita: "Não penses, contudo, que ando por aqui aos tiros armado em parvo. Talvez, realmente, como o Hemingway sustentava, a experiência de guerra seja importante para um homem". ${ }^{20}$ Negativamente quando em Os cus de Judas lembra as tias que diziam que a guerra havia de torná-lo homem e, quando regressa, a tia, enterrando no seu peito uma bengala, diz numa voz fraca amortecida pela dentadura “- Estás magro. Sempre esperei que a tropa te tornasse homem, mas contigo não há nada a fazer". ${ }^{21}$

O segundo tempo, de menor duração, que corresponderia ao retorno de Lobo Antunes da guerra, se refere à transição para o estado democrático, à aliança povo-Movimento das Forças Armadas (MFA), em que a sociedade se via liberta de um longo processo de ditadura, liberdade conquistada com o apoio militar, e o imaginário do povo português passou a uma nova visão das forças armadas como sendo libertadoras, "empenhadas na solução dos problemas básicos das classes populares ou, pelo menos, na minoração das suas carências sociais mais graves. Sendo nova, esta visão não constitui uma ruptura total com a visão que caracteriza o tempo primeiro". ${ }^{22}$ Já a relação entre forças armadas e sociedade no terceiro tempo, que corresponde ao período pós-revolução, é uma relação social-democrata, não tem a ver com a relação populista do tempo primeiro, tampouco com a relação revolucionária do tempo segundo. Segundo Sousa Santos, é uma relação despolitizada como no primeiro tempo, "ao contrário deste e do tempo segundo, o seu elo privilegiado na sociedade civil não são as classes populares mas antes as classes médias”. ${ }^{23}$ Para o sociólogo, as classes médias tornam-se "as mais receptivas ao apelo profissionalizante/modernizante, uma vez que elas próprias se encontram entaladas no dilema: profissionalização ou proletarização". ${ }^{24}$ Uma relação que "pressupõe um bloco político-social hegemónico dominado pela burguesia e congregando a adesão das classes médias e de largos estratos do operariado; este bloco cristaliza-se num estado moderno empenhado no desenvolvimento capitalista". ${ }^{25}$

Esse estudo, que expõe a construção de um imaginário simbólico entre sociedade e forças armadas, é pertinente
22. SANTOS. Os três tempos simbólicos da relação entre as forças armadas e a sociedade portuguesa, p. 25. Segundo o autor, o "tempo das forças armadas na sociedade liberta $\mathrm{e}$ convulsa de 1974-75, dominado pelo modo como as classes urbanas radicalizadas, sobretudo a pequena burguesia $\mathrm{e} o$ operariado industrial, viram nos militares um aliado natural nas tarefas revolucionárias". Idem, ibidem, p. 14.

23. SANTOS. Os três tempos simbólicos da relação entre as forças armadas e a sociedade portuguesa, p. 40 .

24. SANTOS. Os três tempos simbólicos da relação entre as forças armadas e a sociedade portuguesa, p. 40.

25. SANTOS. Os três tempos simbólicos da relação entre as a e a sociedade portuguesa, p. 40.

\begin{tabular}{|c|c|c|}
\hline EM TESE & BELO HORIZONTE & v. 20 \\
\hline
\end{tabular}


para se pensar a construção de uma crítica na obra de Lobo Antunes, tanto a propostas totalizantes, quanto a soluções que no fundo tendem a reafirmar as instâncias do Poder e que acabam por utilizar um discurso que legitima verdades que a experiência de uma guerra pode colocar à prova. Margarida Calafate Ribeiro, à luz de Boaventura de Sousa Santos, irá traçar todo um percurso discursivo, de Camões, Vieira, passando por Fernando Pessoa, até chegar em António Lobo Antunes, João de Melo, Manuel Alegre, entre outros, para apresentar e problematizar, junto a esses textos, uma sociedade periférica que, desde o Império, se imaginou como pertencente ao centro da Europa. É preciso destacar que os poetas que acompanhavam as grandes navegações, em busca do "novo", necessitavam de histórias para narrar, e seus textos, pelo caráter fundador, embora pudessem também apontar as fragilidades de tal empreendimento, contribuíam para divulgar, nos mares navegados, Portugal como o rosto da Europa ou conforme Ribeiro:

Pela voz de Vasco da Gama, pela voz dos marinheiros ou pela voz do poeta, em Os Lusíadas, Portugal é a nação predestinada para dar "novos mundos ao mundo", convertida na terra eleita por Deus, destinada a dominar o mundo como uma nova Roma. É a "cabeça da Europa" no sentido amplo do termo, ou seja, a cabeça do mundo na concepção eurocêntrica sobre a qual o livro é escrito. ${ }^{26}$
Dando um salto histórico até o tempo em que a narrativa de Lobo Antunes se insere e sua importância para se pensar o sonho de expansão em ruína, tem-se a imagem de Salazar, avesso ao diálogo, cujos discursos, pelo seu poder de persuasão (e da força), não permitiam a dúvida e faziam perdurar e incutir esse imaginário até a queda do império colonial em África. Segundo a estudiosa, um discurso dito a um povo em silêncio e a silenciar, onde não se discutia nada:

não se discutia "Deus e a virtude", "a Pátria e a sua História", "a autoridade e o seu prestígio", "a família e a sua moral", "a glória do trabalho e o seu dever" ou "os argumentos dos seus adversários". Apresentava-se antes o "conforto das grandes certezas", formuladas pelo ditador com caráter de lei, como anuncia no modelar discurso (...) proferido em 26 de Maio de $1936 .^{27}$

Esta situação só começaria a se modificar com o discurso literário da década de 1950 e pela intervenção cívica já no marcelismo. Poder-se-ia dizer que a perda da ilusão viria mesmo com as guerras de independência, provocando na sociedade uma fratura e abertura para que forças libertadoras pudessem atuar. Ao se referir a Os cus de Judas, Margarida Ribeiro diz que esse mundo interior (o da casa) projeta-se, em Lobo Antunes: regressos, p. 38.
EM TESE

BELO HORIZONTE

v. 20

N. 2

MAIO-AGO. 2014

VALE. A escrita como resistência em António Lobo Antunes

P. $150-170$
27. RIBEIRO. Uma história de regressos, p. 14. 
28. RIBEIRO. Uma história de regressos, p. 265.

29. Pergunta lançada pela Profa. Dra. Isabel Capeloa Gil ao analisar estes conflitos relativos à Guerra Colonial durante orientação, anotaçoes do encontro com a orientadora no estrangeiro em de abril de 2012, em Lisboa. para o exterior (...) revelando um país igualmente imóvel, gasto e impotente, dominado pelo espectro de Salazar, da PIDE e do Cardeal Cerejeira, e onde os Portugueses viviam como mortos-vivos de um "carnaval defunto", o que nos traz à memória a metáfora da "feira cabisbaixa" com que Alexandre O" Neill descreveu este tempo português. ${ }^{28}$

Iludidos pelo regime, os portugueses que foram faze a vida em África, garantindo a ocupação do território incentivada pelo governo português desde a Conferência de Berlim, e que acreditaram nesse sonho, voltaram na condição de retornados: colonos ou colonizados? ${ }^{29}$ Lobo Antunes se debruça sobre o tema em $O$ esplendor de Portugal (1997), traçando um paralelo entre três irmãos que retornaram e a mãe que ficou em Angola, numa tentativa de diálogo entre personagens, espaços e tempos distintos, diálogo marcado pela incomunicabilidade, por cartas que não encontram seus destinatários: os três se mantendo à margem da sociedade e a mãe sofrendo as consequências da guerra civil que se instaurou no país africano pós-independência. Não perdendo de vista os três tempos analisados por Sousa Santos, percebe-se que a obra de Lobo Antunes apresenta uma ruptura com esse imaginário no plano da enunciação, quando nos aproxima das contradições do discurso do Poder ratificado por parte da sociedade, apresentando personagens imersos num universo quase quixotesco, de sonho e ruína, assim como as literaturas pós-Guerra Colonial parecem apontar. ${ }^{30}$ No entanto, diferentemente de um discurso panfletário, que toma a sua verdade como única, Lobo Antunes não nos dá muita saída, a não ser à luz da leitura e do seu exercício diário de escrita. ${ }^{31}$ Nesse movimento de ler e escrever, há um limiar que permite ao autor transitar por tempos imaginados e tempos vividos para a construção de uma obra que se tornou urgente, além de pensar esse imaginário de que fala Boaventura de Sousa Santos.

Embora ocupando uma posição e ambição diferentes de um campesino, Lobo Antunes se iguala aos outros quando se refere à ração de combate compartilhada. Pensar a obra de Lobo Antunes é pensar no jovem que vai à tropa, na família que o aguarda, na democratização do país e na configuração de uma nova política até as problemáticas enfrentadas pelo Estado português que se alastram até os dias de hoje, pois o país compõe um quadro, conforme Sousa Santos, de sociedade intermédia, semiperiférica, em relação aos outros países da Europa. Interessa perceber como esse universo atravessa sua obra, se tornando matéria fundante de uma escrita que se fez, primeiramente, no interior de uma guerra, uma vez que, a partir das cartas, o leitor passa a não ter dúvidas do efeito dessa experiência na sua escrita. Assim, pode-se afirmar que a experiência da guerra, também do hospital, se tornou fundamental para a constituição de uma obra que deixa
30. Para discutir esse momento, Margarida Calafate Ribeiro elege além de Os cus de Judas (1979), de António Lobo Antunes, Autópsia de um mar em ruínas (1984), de João de Melo, Jornada de África (1989), de Manuel Alegre, e $A$ costa dos murmúrios (1988), de Lídia Jorge.

31. Pensando aqui na escrita literária já que, para a história oficial, os soldados mortos não são nada além de números e, para os excombatentes, o estado constrói monumentos mudos.
EM TESE

BELO HORIZONTE

N. 2

MAIO-AGO. 2014 
transparecer a consciência do seu tempo sem se agarrar às verdades dos discursos institucionalizados ou panfletários, propondo a sua verdade, a do escritor, sobre esses aparatos de controle que incidem violentamente nos sujeitos. Desse modo, adentrar no inferno, no hospital, é constatar a falência de certos procedimentos de controle sobre sujeitos que resistem a serem controlados. Numa escrita desencantada em que não há apaziguamento e nem mesmo o escritor está livre de cometer equívocos, ninguém está a salvo, nem ele mesmo. Importante pensar num autor que sobreviveu a tudo isso e sua tentativa cotidiana de erguer um projeto de vida literária desde a descida aos infernos, quando decide se lançar definitivamente no escrever. Segundo Ribeiro:

No livro de Lobo Antunes e de acordo com várias declarações do escritor, a guerra é o momento de viragem e de tomada de consciência política da situação portuguesa, processo aliás sempre associado à personalidade do 'capitão de óculos moles e dedos membranosos', que lhe diz que a revolução se faz por dentro e é o único militar que goza da simpatia do narrador-personagem [de Os cus de Judas]. Como um bom menino burguês que se retrata no livro, nunca questionou 'as verdadeiras dimensões de Portugal' inscritas no mapa da escola primária ou a censura do canto IX da epopeia nacional. Na Faculdade, a crise de 62 passou-lhe despercebida, entregue ao superficial ambiente pacato que o envolvia, a escrever e a jogar xadrez
À medida que avança para a guerra e vai penetrando nestes cus de Judas geográficos e o extremo das atitudes humanas que transforma os "homens em bichos" -, uma consciência de engano, desespero e revolta vai invadindo. ${ }^{32}$

Nas cartas, Lobo Antunes revela o quão irônica é aquela situação em que jovens são lançados para matar e morrer por uma causa, segundo ele, inconsistente. Em Os cus de Judas, essa situação de guerra será colocada com muito mais aspereza e em tom muitas vezes sarcástico, utilizando também o grotesco para descrever o horror, como na cena do suicídio do soldado em que o queixo, a boca, o nariz, a orelha, pedaços de cartilagens, de ossos e de sangue espalharam-se e cravaram no zinco do teto; questionando sobretudo a virtualidade das verdades impingidas pelo Estado frente à verdade da guerra, bem como os privilégios concedidos aos filhos de ministros e protegidos pelas amantes de pessoas importantes, com atestados falsos de incapacidade de servir o Exército. Como já dito, é possível localizar nas cartas o aproveitamento posterior das cenas experienciadas, ao passo que $O s$ cus de Judas amplia, em tom de ironia, ainda mais os impactos da guerra descritos à esposa, numa narrativa entrecortada, entre o capitão que chegou da mata com uma kalachnikov e o apelo aos soldados portugueses impresso nos papéis do MPLA para que desertem:
32. RIBEIRO. Uma história de regressos, p. 280-81. 
Deserta Deserta Deserta Deserta Deserta DESERTA, a locutora da rádio da Zâmbia perguntava Soldado português porque lutas contra os teus irmãos mas era contra nós próprios que lutávamos, contra nós que as nossas espingardas se apontavam, I love to show you my entire body e eu já me tinha de novo esquecido do teu corpo de coxas afastadas no quarto do sótão onde durante um mês vivi, esquecido do cheiro do sabor da elasticidade suave da tua pele, já me tinha esquecido do som da voz do sorriso dos olhos egípcios irónicos e ternos os seios grandes o cabelo na almofada os dedos perfeitos dos pés, o capitão chegou da mata com uma kalachnikov no sovaco e disse $\mathrm{O}$ tipo estava de costas a guardar a lavra não nos viu sequer aproximar-nos, vamos todos acordar bem dispostos amanhã e ganhar a guerra vivaportugal, que importa o nevoeiro do cacimbo até os ossos se angolénossa e as senhoras do movimento nacional feminino se interessam desveladamente pela gente toma lá dez aerogramas e vai-te curar, compreende o que é querer fazer amor e não haver com quem, a miséria de ter $\mathrm{d}$ masturbar-se a pensar em nada (...) Está a ouvir os gajos sussurava o tenente apontando as sombras, Meu amor querido eis-me outra vez no Chiúme depois de uma viagem sem problemas e isto sabes como é continua na mesma um pouco isolado mas tranquilo no fundo é idêntico a morar dois anos em Vila Real ou em Espinho ou num monte do Alentejo com a vantagem de poder contar à nossa filha que conversei com zebras e elefantes em zebrês e elefan- tês, todas as tardes escrevia ridículas mentiras joviais para uma mulher sem corpo, tendo no bolso o teu retrato a cores sentada numa rocha ao pé do mar de cabelo cortado e óculos escuros pernas cruzadas sob um vestido estampado vermelho e és tu e não és tu quem na fotografia me (me?) sorri, Angolaénossa senhor presidente vivapátria claro que somos e com que apaixonado orgulho os legítimos descendentes dos Magalhães dos Cabrais e dos Gamas e a gloriosa missão que garbosamente desempenhamos é conforme o senhor presidente acaba de declarar no seu notabilíssimo discurso parecida só nos faltam as barbas grisalhas e o escorbuto mas pelo caminho que as coisas levam eu seja cego se não lá iremos, e já agora se me permite porque os filhos dos seus ministros e dos seus eunucos, dos seus eunucos ministros e dos seus ministros eunucos, dos seus miniucos e dos seus eunistros não malham com os cornos aqui na areia como a gente, o capitão encostou a kalachnikov à parede e ficámos surpreendidos a olhá-la, Afinal é este o aspecto da nossa morte perguntou um alferes, senhor doutor tem de ir à mata porque pisaram uma antipessoal num trilho, seis quilômetros de Mercedes disparada e nisto o pelotão numa clareira o cabo Paulo estendido a gemer e do joelho para baixo depois de uma pasta torcida de sangue nada, nada senhor presidente e senhores eunucos nada (...).

Este longo excerto corresponde a pelo menos oito páginas de informações que se sobrepõem umas às outras sem um
33. ANTUNES. Os cus de Judas, p. 125-128; grifo meu. 
ponto final que as encerre. A respiração, se há uma possível, se dá apenas por vírgulas e letras maiúsculas, numa espécie de fluxo de consciência que marcará essa escrita. Sem pretender mimetizar o conteúdo das cartas com o romance, observa-se claramente o distanciamento, na voz desse narrador, da importância que fora essa troca de correspondências para esse jovem no calor dos acontecimentos. Nesse novo momento revisita as lembranças com distanciamento, buscando auxílio na ficção, estando agora em jogo a possibilidade não apenas de narrar as suas impressões sobre aquilo que vivera, mas também demonstrar a sua habilidade em rearranjar como escritor, a memória. É claro que o conteúdo das cartas revela muito mais do que essa descrição em Os cus de Judas, cartas que o leitor ainda não tinha acesso no momento em que fora publicado, ao mesmo tempo sabe-se que revelam muito menos desse impacto da experiência que o romance expõe sem nenhum pudor ou censura: a sua crítica ao Poder, como a sua falta de coragem para desertar.

Se no trecho acima encontram-se fragmentos que indicam contradições (os filhos dos ministros não compartilham da missão colonialista), num jogo irônico que mistura evocações de glória e fervor à pátria (o "notabilíssimo" discurso do senhor presidente, vivapátria, Angolaénossa) e os vultos patrióticos (a descendência de Cabral, Gama e Magalhães), prováveis símbolos a serem recuperados pelo discurso do poder, sem repouso, o narrador de Os cus de Judas segue adiante e mais uma vez a kalachnikov é retomada, num momento em que o desejo de aniquilar a imagem de Salazar aflora numa carta imaginária:

(...) o furriel vomitava aos arrancos abraçado à arma abraçávamo-nos às espingardas como afogados a pedaços de irrisórios de madeira, É este o aspecto da nossa morte interrogava o alferes a apontar a kalachnikov na parede, o aspecto da nossa morte são estes arbustos pindéricos e este homem prostrado cor-de-cinza que delira, o comandante de pelotão assobiava de fúria, Prezado doutor Salazar se você estivesse vivo e aqui enfiava-lhe uma granada sem cavilha pela peida acima uma granada defensiva sem cavilha pela peida acima, injectei segunda ampola de morfina no deltóide, Depois deste trabalho todo não patines, do Chiúme informaram que o helicóptero largara de Gago Coutinho com mais sangue a bordo (...). ${ }^{34}$

A "carta" dirigida a Salazar é um possível "grito" de desespero e raiva, mensagem rompida pelo narrador na ação de injetar morfina num paciente. $\mathrm{O}$ ritmo do texto imprime a atmosfera do desespero. Diferentemente de outras passagens do romance quando o narrador se refere à mulher-ouvinte, esse acréscimo de informações que se dão por encaixes, como a carta à esposa e a Salazar, não soa como um rompimento brusco, ao contrário integram o pensamento, 
35. Importa lembrar que não se trata de uma afirmação da negatividade em Lobo Antunes, ou estabelecer dicotomias entre pretende é apenas apontar

como o autor expõe no texto o efeito da experiência da guerra nos sujeitos e disso não se tem dúvida. Mesmo as lembranças positivas são marcadas por uma positivas são marcadas por uma chamar aqui, "lampejos de ternura" em meio a memória atormentada do personagem corroboram a costura de um assunto no outro sem pausa. Quão legítima pode ser a guerra diante de sangue, pedaços de corpos pelos ares, injeções, ataduras, a morte? $\hat{E}$ possível haver alguma elaboração positiva a se tirar dessa experiência? Ao menos a ternura, como já mencionado, enuncia certa positividade, atribuindo ao texto também um caráter de porosidade e não de uma verdade acabada sobre a guerra: a lembrança que se volta ao jardim zoológico o professor de patinagem a deslizar elipses vagarosas, as moças de saias de folho e de botas brancas, a preguiça dos animais -, à casa da Praia da Maçãs - o ronco do mar e as tábuas do assoalho a ranger, que os assombravam à noite, aos olhos verdes da filha. Ternura essa evidente nas cartas e necessária para o "manter-se vivo". ${ }^{35}$

De toda forma, fica evidente a inutilidade dos monumentos erguidos posteriormente, edificações que em nada servirão para trazer de volta a vida daqueles que morreram em combate, bem como restituir a daqueles que perderam sua juventude e tiveram a memória marcada pelas imagens da guerra. Sobre isso, Vecchi lembra o Monumento Naciona aos Combatentes do Ultramar, erguido em Belém em 1994 período em que o crítico começava a se ocupar do tema da Guerra Colonial e a reunir documentos referentes ao assunto, num momento de reflexão por conta dos vinte anos de Revolução dos Cravos. Segundo o estudioso,
$\mathrm{Na}$ aparência um sinal de conciliação no processo de construção de uma memória pública que se prestaria para uma monumentalização supostamente compartilhada. Na verdade, o monumento-memorial tornou-se controverso, justamente porque, na sua pretensão harmonizadora de condordia discors, diluiu nas ambiguidades da representação (Cfr. Sapega, 2008: p. 29) tensões ainda muito fortes, presentes na sociedade, perante um assunto de certo modo tabu, ou causa de veementes disputas ideológicas (...) O que chamava a atenção (...) era de certo modo o jogo alegórico que o monumento instituía num espaço público dominado pela retórica celebrativa, como Belém: os Jerónimos, o Padrão dos Descobrimentos, a Praça do Império. E o memorial com a listagem dos nomes dos soldados que morreram "ao serviço de Portugal (1954-1975)" mais do que compor uma fractura parece aprofundar um corte na memória e abri-la como território de confronto e embate. ${ }^{36}$

António Lobo Antunes é um dos escritores que coloca em discussão as referências monumentais em contraposição à esfera do vivido. Dialoga com outras referências, sejam do cinema, da literatura, da música, da pintura, apresentando uma possibilidade de leitura crítica do mundo compondo juntamente com essas solicitações, para criar uma narrativa de contraste e uma proposta de questionamento da verdade por trás também das bandeiras ideológicas. Exibindo a fragilidade do homem, denunciando algo irrecuperável, talvez por isso mesmo seja preciso narrar, como em Os cus de Judas:
36. VECCHI. Excepção Atlântica, p.
EM TESE
BELO HORIZONTE
v. 20
N. 2
MAIO-AGO. 2014
VALE. A escrita como resistência em António Lobo Antunes
P. $150-170$ 
37. ANTUNES. Os cus de Judas, $\mathrm{p}$. 122-123.
Éramos peixes, percebe, peixes mudos em aquários de pano e de metal, simultaneamente ferozes e mansos, treinados para morrer sem protestos, para nos estendermos sem protestos nos caixões da tropa, nos fecharem a maçarico lá dentro, nos cobrirem com a Bandeira Nacional e nos reenviarem para a Europa no porão dos navios, de medalha de identificação na boca no intuito de nos impedir a veleidade de um berro de revolta (...) O leitor de cassetes do alferes Eleutério tocava a 4 Sinfonia de Beethoven, e era como se a música soasse numa sala deserta para lá de cujas janelas sem cortinas a chana desdobrava interminavelmente as pregas do seu lado, uma música que se prolongava no eco de si própria do mesmo modo que nos pianos cerrados teimam em morar ainda os compassos ténues de uma valsa antiga (...) Éramos peixes, somos peixes, fomos sempre peixes, equilibrados entre duas águas na busca de um compromisso impossível entre a inconformidade e a resignação, nascidos sob o signo da Mocidade Portuguesa e do seu patriotismo veemente e estúpido de pacotilha, alimentados culturalmente pelo ramal da Beira Baixa, os rios de Moçambique e as serras do sistema Galaico-Duriense, espiados pelos mil olhos ferozes da PIDE. ${ }^{37}$

Perante esse texto, pode-se pensar nesta literatura que se vê diante da violência do mundo e de suas mazelas, podendo propor um questionamento sobre tudo aquilo contrário à vida com palavras que sabe serem insuficientes. Uma literatura talvez herdeira da ironia romântica, mas com olhar não mais distanciado do objeto. Ao contrário, seu olhar está implicado no objeto. $O$ texto não se apresenta como uma tomada de resoluções para os problemas, seria ingenuidade atribuir à literatura esta função, mas não se deve descartar o seu poder de denúncia, mesmo que não seja o objetivo primeiro, dos problemas enfrentados pelo sujeito no pior dos mundos; numa tomada de consciência das questões insolúveis, como a morte, cuja iminência é dada pela situação-limite.

Para Lobo Antunes, que desde criança desejava ter seu nome na capa de um livro, a guerra pode ser compreendida como uma fratura, observada desde a primeira carta. Não sendo pertencente a algum movimento de esquerda, a guerra lhe serve também como reflexão da posição política que ocupava, como em 15 de maio de 1971 escreve:

Começo a compreender que não se pode viver sem uma consciência política da vida: a minha estadia aqui tem-me aberto os olhos para muita coisa que se não pode dizer por carta. Isto é terrível - e trágico. Todos os dias me comovo e me indigno com o que vejo e com o que sei e estou sinceramente disposto a sacrificar a minha comodidade - e algo mais, se for necessário - pelo que considero importante e justo. $\mathrm{O}$ meu instinto conservador e comodista tem evoluído muito, e o ponteiro desloca-se, dia a dia, para a esquerda: não posso continuar a viver como o tenho feito até aqui. ${ }^{38}$
38. ANTUNES. D'este viver aqui neste papel descripto, p. 161

EM TESE

BELO HORIZONTE

v. 20

N. 2

MAIO-AGO. 2014

VALE. A escrita como resistência em António Lobo Antunes

P. $150-170$ 
Mais tarde saberemos que o autor questionará ambos os lados, quando constata o quão corruptível é o Poder, que a liberdade fora aparentemente conquistada, e que as decisões continuam sob o controle do Estado, que seu povo continua a sofrer, conforme declarou em entrevista ao jornal português Público:

- A gente não vive em democracia, como é evidente. Não vive. Há algumas quase democracias - a Holanda, a Bélgica, a Suí ça [com] aquele arranjo [federal] complicado. A democracia implicava um constante referendar pelo povo das decisões do poder. Não existe. ${ }^{39}$

Sobre o escarnecimento em relação à construção do novo Portugal do ponto de vista do regresso, como o narrador de Os cus de Judas vê da janela o cemitério do Alto de S. João que o faz lembrar o Portugal dos Pequeninos, o mundo em miniatura que narra a história de um império, além da imagem recortada do Tejo, a névoa sobre o rio sem barcos, que também dá ideia de ofuscamento da visão, Ribeiro diz:

Após a meteorítica alegria da revolução, o povo parece ter ido de novo para a casa, retomando um Portugal na medida "diminutiva" de um "dia-a-dia funcionário", de luzes e cortinas que se abrem às sete da manhã e se fecham às oito da noite, de casas cheias de ornamentos de feira que, ao mesmo tempo que nos satisfazem o gosto pequenino e ilusório de grandeza, tapam as mazelas da "humidade que se infiltra", das coisas "que empenam", dos "canos que entopem", imagens de um país que tenta enganadamente reerguer-se, procurando ocultar as feridas e ignorar os "lázaros" que quotidianamente se escondem nos caminhos marginais, tentando iludir a sua dor pelas noites, pelo copos e pelos corpos, numa atitude dolorosamente subversiva dessa sociedade pequenina que, num outro contexto, os surrealistas tão acutilantemente tinham denunciado. ${ }^{40}$

Ao invés de reafirmar um ideal ou construir utopias, a busca incansável de Lobo Antunes se dirige à arte de renovar o romance, segundo ele mesmo disse. Ao mesmo tempo, aponta caminhos possíveis e a positividade pode ser encontrada nas imagens tipicamente da infância que abriga a ternura, conforme já dito. $\mathrm{O}$ escritor português, que declarou a Maria Luisa Blanco ler de tudo e que tudo lhe interessa, desde anúncios publicitários, uma frase que escapa, romances, poesias, e biografias de artistas, como Picasso, Mozart etc., demonstra um olhar atento à pluralidade de seu tempo que talvez só pudesse se fazer valer numa escrita errante, fragmentada, instável e violenta. Por exemplo, quando o personagem de Os cus de Judas solicita referências para dar conta do narrar, pontuando essa narrativa com referências ao cinema, à literatura, à musica. Neste outro trecho observa-se,
40. RIBEIRO. Um história de regressos, p. 287. 
41. ANTUNES. D'este viver aqui neste papel descripto, p. 125-26. no entanto, o seu olhar para a cultura local intermediada obviamente, pelo posto que ocupa:

\section{Minha jóia querida}

De novo a chuva em G. Coutinho, e um tempo cinzento e triste. Não sei o que se passa com este cacimbo que não há forma de se decidir a instalar-se definitivamente. No hospital civil, ao fim da tarde, uma multidão variada entra na sala dos doentes, cada um com a sua esteira debaixo do braço, para dormirem à volta das camas onde estão os doentes da famí lia. Os laços familiares são aqui extremamente fortes. Os parentes dos internados constroem cubatas à volta do casarão velho e sem condições do hospital, formando uma autêntica aldeia onde vivem e comem enquanto os internados não têm alta. Desde manhã o ambiente tem qualquer coisa de feira macabra e miserável, com concílios de homens silenciosos acocorados em círculo em torno de um montinho de brasas. ${ }^{4}$

Nesse cenário, apenas um olhar observador e com impulso para a escrita pode se dar conta da diferença cultural sintetizada no simples gesto de carregar uma esteira debaixo do braço, armá-la ao lado da cama para aguardar a cura de um parente. $\mathrm{O}$ que parece estar em evidência, além dos laços familiares, é a relação com a morte. Estar ao lado do parente ferido ou doente é aguardar o momento da cura, mas também o momento em que o espírito se libertará do corpo. Uma vigília marcada por conversas monossilábicas, conforme Lobo Antunes prossegue o relato. Nesta mesma carta, observa-se o teor literário impresso pelo autor, que a partir da descrição desse episódio traz à tona outros tempos e lugares que a cena lhe remete:

Os homens e os cães, que por aqui são abundantes e esqueléticos como os galgos da insólita corte espanhola de Velasquez, cheia de freiras, de deformados físicos e de sombras inquietantes de espectros. Costumo pensar muitas vezes nesse estranho filho de português e nos seus fantasmas e anões, nos fundos negros habitados por alarmantes olhos invisíveis, na luz dos círios Escurial. Até o seu Cristo tem algo da alma profundamente trágica da Espanha, das suas luas de navalhas e dos seus gritos, das suas oliveiras e dos seus painéis fuliginosos. Fazem-me pensar nos cadáveres enterrados nas igrejas, nas estátuas jacentes, nos corvos de pedra dos túmulos, na crueldade romântica da guerra de 36-39, no meu amigo Dom Miguel de Unamuno, no general Milan d'Astray e no seu berro viva la muerte, nos mouros que tomaram a Cidade Universitária de assalto e morriam andar por andar, na poetisa galega Rosalia de Castro e "ver o adolescente afogado", no "vento que muxe", nos penhascos e nas pedras morenas de Compostela, que, desde os 8 anos, nunca mais esqueci, e no nosso pequeno e triste país de viúvas a descer para o mar, com os seus muros brancos, o seu sol, o seu labirinto de ruas e o seu silêncio. ${ }^{42}$
42. ANTUNES. D'este viver aqui neste papel descripto, p. 126 
O trecho acima condensa referências de personalidades (como Velázquez), lugares e fatos historicamente localizáveis (a Guerra Civil da Espanha). Porém, é a partir de um evento, o hospital, que essas imagens são trazidas recuperando ao mesmo tempo o lugar da infância, seus oito anos, onde alguma inocência persiste. A comparação é um dos recursos que o autor mais utiliza e traz à tona referências que serão caras ao texto, como na primeira frase do excerto. No pé de página, há uma observação quanto à citação atribuída a Rosalía de Castro pertencente a García Lorca, provavelmente se tratando de um equívoco. Isso é interessante porque, não tendo como localizar as fontes, o que import é a implicação de um teor comparativo, a remissão a memórias que por sinal podem ser falhadas. Numa perspectiva literária, a incorreção pode ser pensada como um efeito do próprio ato de rememorar, como reinvenção de uma verdade, e, incorporada ao texto, passa a integrar um universo cuja regra pode ser modificada pelo esquecimento. O que parece importar é o fluxo desse pensamento que quer traze para a intimidade tudo aquilo que lhe serve de pretexto para narrar. Por outro lado, num trabalho criterioso, cotejar as referências é importante quando estas elucidam o processo de escrita, menos como esclarecimento do texto, pois o leitor fatalmente se perderia na multiplicidade de referências e leitura lhe pareceria impossível.
Como já assinalado, o conjunto das cartas, que não incluem as enviadas pela esposa, apenas algumas fotos trocadas por ambos, não é exatamente um livro de António Lobo Antunes, e ao mesmo tempo não o deixa de ser. Porém, interessa ao leitor o acesso a algo genuíno, o movimento em busca do narrar e da leitura, talvez como única saída:

Levo já algumas horas de voo nestes pássaros precários, quer em evacuação de feridos quer em visitas aos destacamentos. Hoje, estava em Ninda, fazendo a consulta dos nativos quando ouvi um estrondo abafado e uma subida de fumo. Uma mina tinha acabado de rebentar debaixo de uma viatura nossa, com seis feridos, felizmente pouco graves. $\mathrm{O}$ ataque, a morteirada, acabou por ter poucas consequências, devido a uma sorte incrível. Havia estilhaços por todo o lado. Um deles foi entrar no quarto de um oficial e partiu o fio do candeeiro meio metro acima da cabeça dele. A rádio de Zâmbia, que ouvimos todas as noites, declarou ter feito 3 mortos e 16 feridos, e anuncia para amanhã, dia 4, aniversário do MPLA, o nosso total aniquilamento. Entretanto acabo de receber um maço de cartas, que vêm todas juntas: muitas de ti, três da minha velha, uma do Manuel, outra da tia Gógó. Gostava realmente de ler o livro do Córtazar, embora me falte o tempo e a disposição. Daqui até o fim da semana, se as condições melhorarem, vamos a ver se começo a pensar noutras coisas para além dos doentes e da minha própria sobrevivência. ${ }^{43}$
43. ANTUNES. D'este viver aqui neste papel descripto, p. 39. 
Nesse trecho, imprime o cotidiano impreciso, ao relatar a instabilidade do voo, a presença da rádio da Zâmbia com informações norteadoras, bem como o afeto que lhe chega (o maço de cartas) e o livro que gostaria de ler. Em Os cus de Judas, várias dessas imagens retornarão como matéria da ficção autobiográfica - as cartas enviadas pelos irmãos, as leituras, os sobas, os feridos, a natureza, os lugares -, como nesse trecho da passagem em que narra a chegada do primeiro morto ao acampamento:

(...) o helicóptero transportou-o para Gago Coutinho como quem varre lixo vergonhoso para debaixo de um tapete, morre-se mais nas estradas de Portugal do que na guerra de África, baixas insignificantes e adeus até ao meu regresso, o furriel arrumou os instrumentos cirúrgicos na caixa cromada, os canivetes, as pinças, os porta-agulhas, as sondas, sentou-se ao meu lado nos degraus do posto de socorros, espécie de vivenda pequenina para férias de reformados melancólicos, mordomos idosos, governantas virgens, os eucaliptos de Ninda não cessam de aumentar, estamos os dois aqui sentados agora como ele e eu nesse tempo, Abri de 71, a dez mil quilómetros da minha cidade, da minha mulher grávida, dos meus irmãos de olhos azuis cujas cartas afectuosas se me enrolavam nas tripas em espirais de ternura $(. . .)^{44}$
Ao mesmo tempo em que a leitura das cartas pode soar como uma invasão na dor do escritor empírico diante da guerra e da angústia de seu empreendimento de escrita, tendo em vista uma destinatária empírica, também parece permitir outros destinatários; o relato da desistência do corpo e o fato de não conseguir empreender a tranquilidade desejada para escrever não chega ao leitor como mera especulação; relato que também se confunde com o do personagem anônimo de Os cus de Judas. As cartas que funcionam como a apresentação do desejo de que venha à tona um projeto (sintomaticamente, ou não, a iniciar-se na guerra) trazem o gesto cuidadoso do futuro escritor. Projeto necessário e urgente, como o leitor pode constatar. Entende-se que o momento inicial foi sendo repensado e atualizado no processo da escrita, não apenas dos primeiros romances, mas também dos que se seguiram, o que supõe uma leitura constante para a correção perpétua, deixando transparecer em sua obra a consciência da construção literária. Nesse sentido, Guerra e paz, A morte de Ivan Illitch, O processo são alguns dos livros que anuncia nas cartas como seus preferidos. Também Kaputt, um livro famoso do correspondente de guerra da imprensa italiana Curzio Malaparte, que pôde testemunhar, de dentro do lado nazi-fascista, o horror da Segunda Grande Guerra, rompendo mais tarde com o partido, passando a ser perseguido pela Gestapo.
44. ANTUNES, Os cus de Judas, $\mathrm{p}$. 70-72; grifo meu.
EM TESE

BELO HORIZONTE

v. 20

N. 2

MAIO-AGO. 2014

VALE. A escrita como resistência em António Lobo Antunes

P. $150-170$ 
45. ANTUNES. D'este viver aqui neste papel descripto, p. 26

46. ANTUNES. D'este viver aqui neste papel descripto, p. 255
Paralelamente ao combate, à cura dos feridos e auxílio à comunidade, escreve e resiste ao sofrimento e à falta de consolo, como na carta de 21 de janeiro de 1971 confirma: “(...) a verdade é que sofro como um cão e não tenho ninguém quem dizer, porque os que estão comigo sofrem tanto como eu". ${ }^{45}$ Depois, a 28 de julho de 1971, diz:

Nesta terra tenho enterrado os melhores meses da minha vida, e se calhar, também, a maior parte dos anos da minha velhice. Isto gasta por dentro como um cancro. E o que mais me custa é o coeficiente de absurdo desta aventura. E um preço caro o que estou a pagar para poder um dia viver aí. E penso tanto que é um preço caro demais! E tu, então, casada com uma espécie d fantasma! Eu queria pedir-te desculpa por esta separação e este tão longo e melancólico sofrimento. ${ }^{46}$

Na contrapartida da experiência traumática, como aponta Vecchi, Fernando Assis Pacheco, um dos precursores da literatura da Guerra Colonial, cria, a partir da troca paratextual-paronomástica ao converter o Viagens na minha terra garrettiano em Viagens na minha guerra (1972), a guerra como um elemento de literatura, atestando, assim como Garrett:

a impossibilidade de extrapolar uma narrativa dos restos inacessíveis de uma Santarém espectral, de ruínas mudas que não significam mais nada (...) o poeta da dupla escrita toponomás-
BELO HORIZONTE tica (...) mostra também a consciência de que os escombros - as ruínas ou os restos mudos - da experiência da guerra não produzem nenhum "real" (...) que é concretamente o "campo de batalha", como no caso dos nomes da guerra, onde a literatura da guerra colonial se põe em jogo. ${ }^{47}$

Perante o exposto, pode-se considerar que António Lobo Antunes também elegerá posteriormente a guerra como elemento de literatura. Não apenas como tema, mas, sobretudo, pela descentralização e fragmentação, tanto dos sujeitos inscritos, quanto do texto em si. Influenciado ou não, como argumenta, pelo cânone. ${ }^{48} \mathrm{O}$ rastro deixado pelos seus eleitos apresenta um valor de significante, seja para se pensar a memória sua fragmentação e descontinuidade, ou a própria escrita cuja palavras que são "poucas e gastas" e, por isso, não se pode tudo dizer ou compreender. Suas referências não interessam, portanto, como influência direta e sim como vestígios de um leitor insone. Nesse caso, existem dois nomes significativos que sintetizam essa relação com a memória: Kafka e Proust. Não no sentido de localização da atmosfera e procedimento de escrita. Mas o que representam como inacabamento e incomunicabilidade, no caso do primeiro, e máquina de movimentar memórias, no caso do segundo, bem como o esforço diário de escrita, da correção perpétua em ambos.

$\mathrm{Na}$ guerra, as correspondências são também alimento. Bem como a comida, remédios e munição, as cartas, junto
47. VECCHI. Excepção At/ântica, p. 28.

48. Pensando aqui em seus eleitos: Faulkner e Conrad, cujos Faulkner ênrad, cujos forma fragmentada da escrita por histórias paralelas que nem sempre se encaixam umas nas outras, como o faulkneriano Palmeiras selvagens, afirmando um procedimento de marcado pela descentralização narrativa. 
49. ANTUNES. D'este viver aqui neste papel descripto, p. 37. a elas as fotografias e prendas trocadas, têm papel fundamental para a tropa, alimentando o soldado de alguma esperança para além da situação que o tornara caça e caçador. Lobo Antunes irá falar da importância dos envelopes que chegam. Como em 10 de fevereiro de 1971: "A vida, nestas paragens, é tão isolada e triste (as demoras dos jornais são de semanas) que as cartas são a coisa mais importante do mundo para nós". ${ }^{49}$ Num contexto geral, pode-se pensar nesse jovem soldado que aguarda as missivas que chegam junto a alimentos frescos, remédios e munição, se prendendo aos aerogramas editados pelo Movimento Nacional Feminino e transportados por cortesia pela TAP como migalhas ou priscas de cigarro lançadas ao chão. Descendo o mais baixo que se poderia descer, muito abaixo do padrão de comportamento burguês, como o poeta moderno, para se manter lúcido e preso a uma esperança de regresso. Fazendo da escrita a sua resistência.

\section{REFERÊNCIAS}

A CORREÇÃO PERPÉTUA. Entrevista com António Lobo Antunes. Folha de São Paulo, Caderno Mais!, São Paulo, 4 de dez.

2005. Disponível em: <http://www1.folha.uol.com.br/fsp/mais/ fs0412200505.htm > Acesso em: 4/12/2005.

ANTUNES, António Lobo. Conhecimento do inferno. 15 ed. Lisboa: Publicações D. Quixote, 2010.
ANTUNES, António Lobo. D'este viver aqui neste papel descripto. Lisboa: Publicações D.

Quixote, 2005

ANTUNES, António Lobo. Memória de elefante. 27 ed. Lisboa: Publicações D. Quixote, 2009

ANTUNES, António Lobo. Os cus de Judas. Rio de Janeiro: Objetiva, 2003.

ARNAUT, Ana Paula (Org.). António Lobo Antunes: Confissões do Trapeiro (1979-2007). Coimbra: Almedina, 2008.

BLANCO, Maria Luisa. Conversas com António Lobo Antunes. 2. ed. Lisboa: Dom Quixote, 2002.

GAGNEBIN, Jeanne Marie. Apagar os rastros, recolher os restos. In: SEDLMAYER, Sabrina; GINZBURG, Jaime (Orgs). Walter Benjamin: rastro, aura e história. Belo Horizonte: UFMG, 2012. p. 27-38.

PÚBLICO. Entrevista com António Lobo Antunes nos Seus 25 Anos de Carreira: "Acho Que Já Podia Morrer". Lisboa, 9 de novembro de 2004. Disponível em <https://groups.yahoo.com/ neo/groups/infoprojecto21/conversations/messages/572>. Acesso em 02 jan. 2005

RIBEIRO, Margarida Calafate. Uma história de regressos Império, Guerra colonial e Pós-colonialismo. Porto: Afrontamento 2004 
SANTOS, Boaventura de Sousa. Os três tempos simbólicos

da relação entre as forças armadas e a sociedade portuguesa.

Disponível em: <http://www.boaventuradesousasantos.pt/media/

pdfs/Tres tempos_simbolicos_RCCS15-16-17.PDF> Acesso em: 27/03/2012.

SEDLMAYER, Sabrina; GUIMARÃES, César; OTTE, Georg

Otte (Orgs.). O comum e a experiência da linguagem. Belo

Horizonte: UFMG, 2007. p 15-27.

SEIXO, Maria Alzira. As flores do inferno. Lisboa: Publicações Dom Quixote, 2010. (volume II de Os romances de António Lobo Antunes)

SEIXO, Maria Alzira (Org.). Dicionário da obra de António Lobo Antunes. v. I e II. Lisboa: Imprensa Nacional-Casa da Moeda, 2008.

SEIXO, Maria Alzira. Os romances de António Lobo Antunes. Lisboa: Publicações Dom Quixote, 2002.

VECCHI, Roberto. Excepção Atlântica: pensar a literatura da Guerra Colonial. Porto: Afrontamento, 2010. 